\title{
DNA repair deficiency in peripheral blood lymphocytes of endometrial cancer patients with a family history of cancer
}

\author{
Lyubov Buchynska ${ }^{1 \dagger}$, Olga Brieieva ${ }^{1 *}$, Nadiia Glushchenko ${ }^{1+}$, Ludmila Vorobyova ${ }^{2 \dagger}$ and Olena Bilyk ${ }^{1 \dagger}$
}

\begin{abstract}
Background: Individual susceptibility to endogenous and/or exogenous DNA damage depends on DNA repair efficiency and can be evaluated using the comet assay with bleomycin as genotoxic agent. The aim of the study was to evaluate baseline and bleomycin-induced DNA damage and DNA repair capacity in peripheral blood lymphocytes (PBLs) of endometrial cancer (EC) patients considering a family history of cancer.

Methods: DNA damage was analyzed in PBLs of 45 EC patients compared to a control group of 10 healthy women, using the comet assay. The level of DNA damage was determined by the\% tail DNA.

Results: The level of baseline DNA damage in PBLs of EC patients was significantly higher (\% DNA in tail $9.31 \pm 15.32$ ) than in healthy women (\% DNA in tail $3.41 \pm 4.71)(P<0.01)$. PBLs of EC patients repaired less bleomycin-induced DNA damage (removed\% DNA in tail $63.94 \pm 20.92$ ) than PBLs of healthy individuals (removed\% DNA in tail $80.24 \pm 3.03$ ) ( $P$ <0.001). Efficiency of DNA repair in PBLs of EC patients depended on the family history of cancer. The amount of restored damaged DNA was significantly lower (removed\% DNA in tail $36.24 \pm 14.05 \%$ ) in EC patients with a family history of cancer compared to patients with sporadic EC (removed\% DNA in tail $64.91 \pm 19.36 \%)(P<0.004)$.

Conclusions: Lymphocytes of EC patients are characterized by an increased basal level of DNA damage as well as deficiency in DNA repair. DNA repair is less efficient in PBLS of EC patients with a family history of cancer compared to patients with sporadic cancer.
\end{abstract}

Keywords: DNA damage, Bleomycin, DNA repair capacity, Endometrial cancer, Family history of cancer, Comet assay

\section{Background}

The cell genome is constantly exposed to endogenous and/or exogenous genotoxic agents causing structural DNA changes which have potentially tremendous cellular consequences. The ability of a cell to decrease or eliminate entirely DNA damage depends on a variety of factors including the nature of the DNA damage and efficiency of DNA repair. A deficiency in DNA repair capacity leads to greater DNA damage mediated by genotoxic agents and may result in accumulated DNA damage. Both these factors exponentially contribute to increasing the risk for cancer through genomic instability [1-3].

\footnotetext{
* Correspondence: olha.brie@gmail.com

${ }^{\dagger}$ Equal contributors

'R.E. Kavetsky Institute of Experimental Pathology, Oncology and

Radiobiology, NAS of Ukraine, Kyiv, Ukraine

Full list of author information is available at the end of the article
}

Human cancers have been shown to demonstrate greater genomic instability compared with the normal tissue in the same host. However, several studies report genomic instability not only in cancer but also in somatic non-cancer cells of cancer patients, particularly in peripheral blood lymphocytes (PBLs) [4-11]. These studies hypothesize that the level of genome damage in PBLs suggests an individual susceptibility to cancer [12-14].

To date, little is known about spontaneous genome damage in PBLs of cancer patients with a family history of cancer. Smith et al. did not find any correlation between DNA damage in PBLs of breast cancer patients and a family history of cancer [12]. In contrast, Roy et al. [13] have demonstrated that PBLs of breast cancer patients and their healthy blood relatives with a family history of cancer were highly sensitive to genotoxic 
effect of bleomycin as compared to controls. Moreover, an increased level of chromosomal aberrations was found in PBLs of colorectal cancer patients with a family history of cancer [14].

It is well known that endometrial cancer (EC) may arise within hereditary cancer syndromes (Lynch syndrome, Li-Fraumeni syndrome, etc.). In addition, patients with EC may have a family history of malignant tumors of organs of the female reproductive system, gastrointestinal tract and some others associated to Lynch syndrome [15-17]. One study has reported the presence of an increased frequency of chromosomal aberrations and breaks at fragile sites of chromosomes in PBLs from EC patients with a family history of cancer compared to PBLs from EC patients without such a family history [18]. The observed chromosomal instability in PBLs may be caused either by inherited susceptibility to genotoxic exposure or by low ability to repair DNA lesions. Therefore, a study to evaluate the sensitivity of PBLs to genotoxic mutagens and the DNA repair capacity in EC patients with a family history of cancer is important. Such approach could contribute to an efficient selection of family members at high risk for cancer and help design cancer prevention strategies for individuals at risk.

The aim of the study was to analyze the level of DNA damage and DNA repair efficiency in peripheral blood lymphocytes of EC patients, taking into account whether or not they had a family history of cancer.

\section{Methods}

Forty five patients with endometrial cancer (EC) stage I and II and ten healthy women were included in the study after having obtained signed informed consent. The number of participants had sufficient statistical power to obtain statistically significant results. EC patients underwent surgical treatment at the gynecological oncology department of the National Cancer Institute, Kyiv, Ukraine. All studied tumors were classified as endometrioid adenocarcinomas. The mean age of the EC patients was 60 years, while that of healthy individuals was 55.7 years. The study was approved by the Committee for Ethical Issues of the R.E. Kavetsky Institute of experimental pathology, oncology and radiobiology, National Academy of Sciences of Ukraine.

A standardized questionnaire was used to collect information on family history of cancer, age, work environment, medications, smoking status, alcohol consumption and nutritional factors. Only EC patients with approximately the same lifestyle were included in this study. We selected 12 of the 40 (30\%) of the EC patients with a strong family history of cancers of female reproductive organs (endometrium and ovary), gastrointestinal tract and some other cancers associated to Lynch syndrome [15-17].
Venous blood samples were obtained by venipuncture and collected into EDTA tubes before patients had received any chemotherapy or radiation therapy. Lymphocytes from whole blood were isolated by centrifugation through Ficoll-Hypaque.

Analysis of baseline and bleomycin-induced DNA damage was performed on freshly isolated PBLs using an alkaline comet assay $[19,20]$. Briefly, microscope slides were first covered with a $1 \%$ normal melting point agarose. Then, $1-2 \times 10^{5}$ of cells were embedded into $75 \mu \mathrm{L}$ of $1 \%$ low-melting point agarose at $37^{\circ} \mathrm{C}$ and the gel was cast over the first agarose layer. To study genotoxic DNA damage, lymphocytes were treated with bleomycin at concentration $20 \mu \mathrm{g} / \mathrm{ml}$ in phosphate buffered saline (PBS), $\mathrm{pH} \mathrm{7.4,} \mathrm{for} 30 \mathrm{~min}$, as recommended by Schmezer et al. [20]. DNA repair capacity was evaluated as the extent of removal of damage in lymphocytes after immersion slides into PBS without bleomycin and incubation for $15 \mathrm{~min}, 37^{\circ} \mathrm{C}$. As a positive control, lymphocytes treated with $100 \mu \mathrm{M} \mathrm{H}_{2} \mathrm{O}_{2}$ for 5 min were used. Then slides were immersed into a lysis solution $(2.5 \mathrm{M}$ $\mathrm{NaCl}, 100 \mathrm{mM}$ EDTA, $10 \mathrm{mM}$ Tris, 10\% DMSO, 1\% Triton X-100, pH10) and kept for an hour at $4^{\circ} \mathrm{C}$. After cell lysis, slides were placed in a horizontal gel electrophoresis unit filled with alkaline electrophoresis buffer (300 mM NaOH, $1 \mathrm{mM}$ EDTA, pH13). After $20 \mathrm{~min}$ of alkali treatment, electrophoresis was performed for $20 \mathrm{~min}$ at $0.8 \mathrm{~V} / \mathrm{cm}$. Slides were then neutralized $2 \times 10$ min using neutralization buffer (0.4 M Tris, pH 7.5) and stained with SYBR Green I. Comets were analyzed using the computer-based image analysis system CometScore (TriTek Corp., Sumerduck, VA, USA). The level of DNA damage was expressed as\% DNA in tail.

Data were analyzed using Statistica 8.0 (StatSoft, Inc.) software. To compare differences between groups, the Mann-Whitney nonparametric test was used with a significance level of $\mathrm{P}<0.05$.

\section{Results}

We observed a significantly $(\mathrm{P}<0.01)$ higher baseline DNA damage in EC patients (\% DNA in tail $9.31 \pm$ 15.32 ) as compared with healthy individuals (\% DNA in tail $3.41 \pm 4.71$ ) (Table 1, Figure 1). The net bleomycininduced DNA damage was assessed by subtracting the basal\% DNA in tail from the\% DNA in tail obtained after incubating the PBLs with bleomycin. It was observed that it didn't differ significantly in EC patients (\% DNA in tail $89.35 \pm 3.99$ ) compared to healthy individuals (\% DNA in tail 84.20 \pm 5.38 ). However, we found differences after we removed bleomycin and studied DNA damage repair. The level of DNA damage in PBLs decreased within the first 15 min after removal of bleomycin, both in healthy individuals and in EC patients (Table 1, Figure 1). However, it was observed that the 
Table 1 DNA damage in peripheral blood lymphocytes of EC patients

\begin{tabular}{lccr}
\hline $\begin{array}{c}\text { Groups of examined } \\
\text { patients }(\mathbf{n}=\mathbf{5 5})\end{array}$ & \multicolumn{2}{c}{ \% tail DNA mean \pm SD } \\
\cline { 2 - 4 } & Baseline DNA damage & Net bleomycin-induced DNA damage & Removed DNA damage \\
\hline Healthy individuals $(n=10)$ & $3.41 \pm 4.71$ & $84.20 \pm 5.38$ & $80.24 \pm 3.03$ \\
EC patients $(n=45)$ & $9.31 \pm 15.32^{*}$ & $89.35 \pm 3.99$ & $63.94 \pm 20.92^{*}$ \\
\hline
\end{tabular}

*Difference is significant in respect to the control group $(p<0.05)$.

level of DNA damage restored in PBLs of EC patients was significantly $(\mathrm{P}<0.001)$ lower (removed\% DNA in tail $63.94 \pm 20.92)$ than in PBLs of control individuals (removed\% DNA in tail $80.24 \pm 3.03$ ). Most importantly, we noted $80-100 \%$ recovery of bleomycin-induced DNA damage in $70 \%$ of healthy individuals and in only $12 \%$ of EC patients (Figure 2).

To determine the significance of hereditary factor for genetic instability in PBLs, we studied the level of baseline DNA damage, bleomycin sensitivity and DNA repair capacity in EC patients in relation to a family history of cancer. We did not observe any significant increase in background DNA damage in PBLs of EC patients with a family history of cancer (\% DNA in tail $10.35 \pm 16.35$ ) compared to those with no family history of cancer (\% DNA in tail 9.51 \pm 15.71 ) (Table 2). The net bleomycininduced DNA damage also did not differ significantly between the two groups (\% tail DNA $91.09 \pm 2.52$ and $88.56 \pm 4.25$ respectively). However, significant difference ( $\mathrm{P}<0.004)$ in repair efficiency was found among these patients. By further incubating cells in PBS without bleomycin, PBLs of EC patients with a family history of cancer
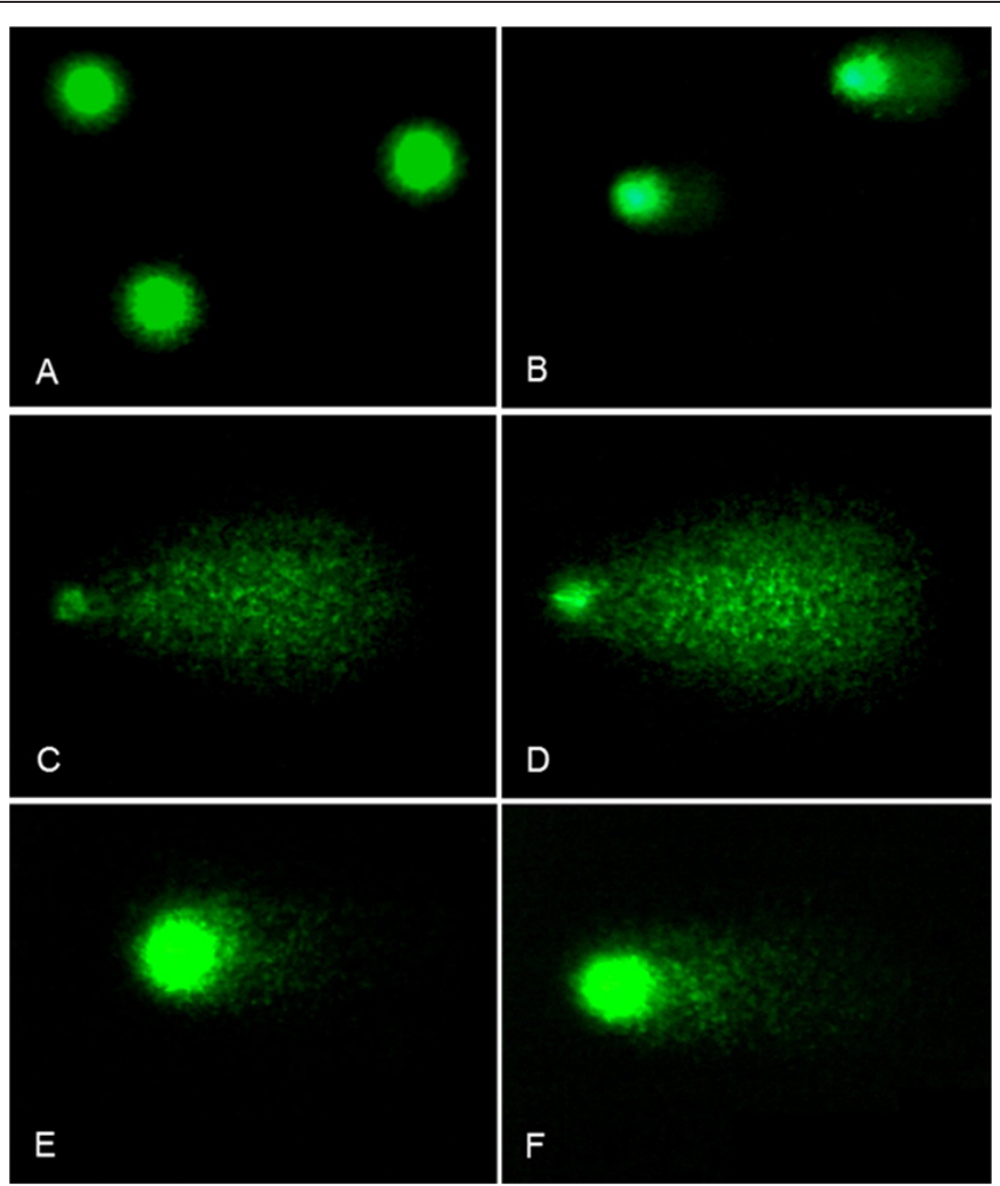

Figure 1 Examples of DNA comets obtained by comet assay in peripheral blood lymphocytes of healthy individuals $(A, C, E)$ and EC patients (B, D, F). A, B. Baseline DNA damages; C, D. DNA damage after bleomycin exposure; E, F. DNA damage remained after repair. 


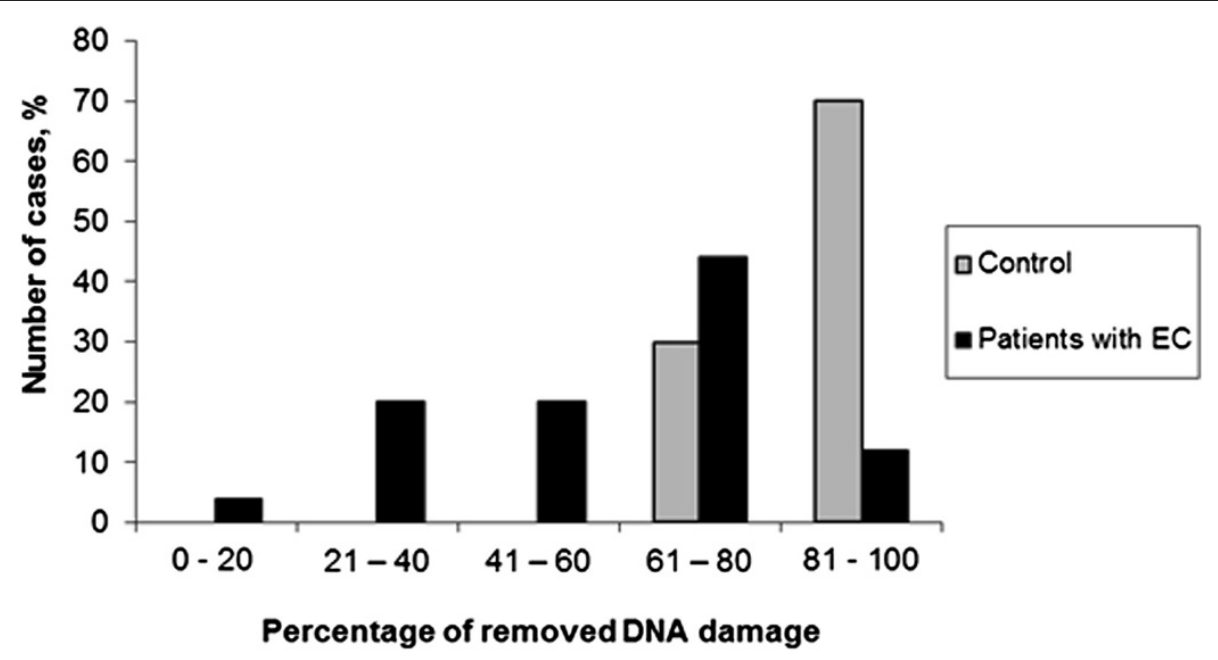

Figure 2 Bleomycin-induced DNA damage removed in PBLs of healthy individuals and EC patients.

were able to repair less bleomycin-induced DNA damage (removed\% tail DNA 36,24 $\pm 14,05$ ) compared to patients with no family history of cancer (removed\% tail DNA $64,91 \pm 19,36$ ) (Table 2).

\section{Discussion}

The results of our study indicate that lymphocytes of EC patients are characterized by pronounced genome instability resulting in increased basal level of DNA damage and deficiency in DNA repair. However one of the limitations of this study was the small sample size we did observed significantly higher baseline DNA damage in EC patients than in healthy individuals which is in agreement with other studies using the comet assay as the study endpoint. Higher baseline DNA damage in lymphocytes was observed in breast cancer patients in comparison with healthy volunteers [11,12]. KurzawaZegota et al. showed that lymphocytes from colon cancer patients had greater baseline DNA damage than those from healthy individuals and this higher level of damage was also observed throughout in vitro treatment with genotoxins [21]. Moreover, in the study of Najafzadeh et al. it has been identified that peripheral lymphocytes from patients with cancers (malignant melanoma and colorectal cancer) or their precancerous states were more sensitive to a generic mutagen than lymphocytes from healthy individuals [22]. The study of Schmezer et al. did not detect any significant difference between the levels of baseline DNA damage in lymphocytes of lung cancer patients and healthy individuals but found an increased sensitivity of lymphocytes to bleomycin and decreased DNA repair capacity in cancer patients [20]. The deficient DNA repair in lymphocytes of lung, head and neck cancer patients also has been shown by other researchers $[4,5,8,9]$. It should be mentioned that the concentration of bleomycin $(20 \mu \mathrm{g} / \mathrm{ml})$ recommended by Schmezer et al., which we also used in our study, caused DNA damage at saturation level of the assay. Therefore, we consider that in further research it is more appropriate to use lower concentration of bleomycin, thus increasing the accuracy of measurements of bleomycin sensitivity and DNA repair.

There is no consensus on the causes of genetic instability in lymphocytes of cancer patients. Probably, genome instability in lymphocytes is the result of the influence of reactive oxygen species, increased levels of which were detected in blood of cancer patients [23,24]. In this way, oxidative stress is observed in breast, lung and colon cancer patients [25-27]. In addition, DNA damage in lymphocytes may also be influenced by tumor-associated factors [12]. Furthermore, reduced repair may lead to an increase in the steady state level of DNA damage.

One study reported that family history of cancer did not have a significant effect on the level of DNA damage

Table 2 DNA damage in peripheral blood lymphocytes of EC patients related to a family history of cancer

\begin{tabular}{lccc}
\hline \multicolumn{1}{c}{ Groups of examined patients $(\mathbf{n}=\mathbf{4 0})$} & \multicolumn{3}{c}{ \% tail DNA mean \pm SD } \\
\cline { 2 - 4 } & Baseline DNA damage & Net bleomycin-induced DNA damage & Removed DNA damage \\
\hline Patients with a family history of cancer $(n=12)$ & $10.35 \pm 16.35$ & $91.09 \pm 2.52$ & $36.24 \pm 14.05$ \\
Patients with no family history of cancer $(n=28)$ & $9.51 \pm 15.71$ & $88.56 \pm 4.25$ & $64.91 \pm 19.36^{*}$ \\
\hline
\end{tabular}

${ }^{*}$ Difference is significant in respect to the group of patients with a family history of cancer $(p<0.05)$. 
in lymphocytes [12]. We also did not find any correlation between a family history of cancer and DNA damage in lymphocytes of EC patients. However, we indeed observed lower DNA repair capacity in lymphocytes of EC patients with a family history of cancer. Perhaps altered DNA repair may be caused by inherited genetic defects and differences in DNA repair capacity reflect individual genetic background leading to different level of genetic instability [5].

We suggest that the comet assay with the use of bleomycin as genotoxic agent is an acceptable way for identifying EC patients with a high level of genome instability. In addition, this assay might be a necessary step for determination of individuals at high risk for cancer among EC patients' relatives. Further research on genome instability in lymphocytes of cancer patients is needed to investigate its significance for cancer prevention and to identify how well these surrogate cells reflect events at the level of the target tumor tissue.

\section{Conclusions}

The results of our study confirm the importance of measuring the individual capacity to repair DNA damage in EC patients especially in those with a family history of cancer. In the present study, the DNA repair efficiency significantly differs from controls to EC patients and from EC patients with a family history of cancer to those with sporadic cancer. We assume that reduced DNA repair efficiency in peripheral blood lymphocytes of EC patients may reflect the cancer predisposition.

\section{Abbreviations \\ EC: Endometrial cancer; PBLs: Peripheral blood lymphocytes.}

\section{Competing interests}

The authors declare that they have no competing interests.

\section{Authors' contributions}

LB designed research and directed study implementation. OB carried out the comet assay and data analysis. NG performed statistical analysis. LV recruited patients. OB edited the manuscript. All authors read and approved the final manuscript.

\section{Acknowledgements}

We are grateful to Prof. Andrew Collins for the valuable comments on the manuscript. The study is supported by the National Academy of Sciences of Ukraine research grant \#0110U005761.

\section{Author details}

${ }^{1}$ R.E. Kavetsky Institute of Experimental Pathology, Oncology and Radiobiology, NAS of Ukraine, Kyiv, Ukraine. ${ }^{2}$ National Cancer Institute, Kyiv, Ukraine.

Received: 2 December 2013 Accepted: 9 October 2014

Published: 15 October 2014

\section{References}

1. Hanahan D, Weinberg RA: Hallmarks of cancer: the next generation. Cell 2011, 144:646-674

2. Pikor L, Thu K, Vucic E, Lam W: The detection and implication of genome instability in cancer. Cancer Metastasis Rev 2013. doi:10.1007/s10555-013-9429-5.
3. Aguilera A, Gómez-González B: Genome instability: a mechanistic view of its causes and consequences. Nat Rev Genet 2008, 9:204-217.

4. Orlow I, Park BJ, Mujumdar U, Patel H, Siu-Lau P, Clas BA, Downey R, Flores R, Bains M, Rizk N, Dominguez G, Jani J, Berwick M, Begg CB, Kris MG, Rusch W: DNA damage and repair capacity in patients with lung cancer: prediction of multiple primary tumors. J Clin Oncol 2008, 26:3560-3566.

5. Spitz MR, Wei Q, Dong $Q$, Amos $C l$, Wu X: Genetic susceptibility to lung cancer: the role of DNA damage and repair. Cancer Epidemiol Biomarkers Prev 2003, 12:689-698.

6. Krupa R, Sobczuk A, Poplawski T, Wozniak K, Blasiak J: DNA damage and repair in endometrial cancer in correlation with the hOGG1 and RAD51 genes polymorphism. Mol Biol Rep 2011, 38(2):1163-70.

7. Hille A, Hofman-Hüther H, Kühnle E, Wilken B, Rave-Fränk M, Schmidberger $H$, Virsik P: Spontaneous and radiation-induced chromosomal instability and persistence of chromosome aberrations after radiotherapy in lymphocytes from prostate cancer patients. Radiat Environ Biophys 2010, 49:27-37.

8. Walczak A, Rusin P, Dziki L, Zielinska-Blizniewska H, Olszewski J, Majsterek I: Evaluation of DNA double strand breaks repair efficiency in head and neck cancer. DNA Cell Biol 2012, 31:298-305.

9. Saha DT, Davidson BJ, Wang A, Pollock AJ, Orden RA, Goldman R: Quantification of DNA repair capacity in whole blood of patients with head and neck cancer and healthy donors by comet assay. Mutat Res 2008, 650:55-62

10. Burgaz S, Coskun E, Demircigil GC, Kocabas NA, Cetindag F, Sunter O, Edinsel $\mathrm{H}$ : Micronucleus frequencies in lymphocytes and buccal epithelial cells from patients having head and neck cancer and their first-degree relatives. Mutagenesis 2011, 26:351-356.

11. Santos RA, Teixeira AC, Mayorano MB, Carrara HH, Andrade JM, Takahashi CS: Basal levels of DNA damage detected by micronuclei and comet assays in untreated breast cancer patients and healthy women. Clin Exp Med 2010, 10:87-92.

12. Smith TR, Miller MS, Lohman KK, Case LD, Hu JJ: DNA damage and breast cancer risk. Carcinogenesis 2003, 24:883-889.

13. Roy SK, Trivedi AH, Bakshi SR, Patel SJ, Shukla PH, Bhatavdekar JM, Patel DD, Shah PM: Bleomycin-induced chromosome damage in lymphocytes indicates inefficient DNA repair capacity in breast cancer families. J Exp Clin Cancer Res 2000, 19:169-173.

14. Nesina IP, Polishchuk LZ, Oliynichenko PI: The determination of chromosomal fragile sites in the peripheral blood lymphocytes of the patients with colorectal cancer in consideration of oncopathology aggregation in family history. Cytol Genet 2000, 34:3-10. Russian.

15. Lancaster JM, Powell CB, Kauff ND, Cass I, Chen LM, Lu KH, Mutch DG, Berchuck A, Karlan BY, Herzog TJ: Society of Gynecologic Oncologists Education Committee statement on risk assessment for inherited gynecologic cancer dispositions. Gynecol Oncol 2007, 107:159-162.

16. Akulenko LV: Hereditary cancer of reproductive system of women. Oncogynecology 2012, 1:24-31. Russian.

17. Chudina AP: Lynch syndrome and sporadic colorectal cancer: clinical and genealogical features. Russ Can J Oncol 2012, 3:11-14. Russian.

18. Chekhun WF, Polishchuk LZ, Buchynska LH: Clinical oncogenetics. In Genetic Medicine. Edited by Zaporozhan BH. Odessa: Odessa Medical University; 2008:222-262. Russian.

19. Dusinska M, Collins AR: The comet assay in human biomonitoring: gene-environment interactions. Mutagenesis 2008, 23:191-205.

20. Schmezer P, Rajaee-Behbahani N, Risch A, Thiel S, Rittgen W, Drings P Dienemann H, Kayser KW, Schulz V, Bartsch H: Rapid screening assay for mutagen sensitivity and DNA repair capacity in human peripheral blood lymphocytes. Mutagenesis 2001, 16:25-30.

21. Kurzawa-Zegota M, Najafzadeh M, Baumgartner A, Anderson D: The protective effect of the flavonoids on food-mutagen-induced DNA damage in peripheral blood lymphocytes from colon cancer patients. Food Chem Toxicol 2012, 50:124-129.

22. Najafzadeh M, Baumgartner A, Gopalan R, Davies JB, Wright A, Reynolds PD, Anderson D: In vitro sensitivities to UVA of lymphocytes from patients with colon and melanoma cancers and precancerous states in the micronucleus and the Comet assays. Mutagenesis 2012, 27:351-357.

23. Kryston TB, Georgiev AB, Pissis P, Georgakilas AG: Role of oxidative stress and DNA damage in human carcinogenesis. Mutat Res 2011, 711:193-201.

24. Mantovani A, Allavena P, Sica A, Balkwill F: Cancer-related inflammation. Nature 2008, 454:436-444. 
25. Atukeren P, Yavuz B, Soydinc HO, Purisa S, Camlica H, Gumustas MK, Balcioglu I: Variations in systemic biomarkers of oxidative/nitrosative stress and DNA damage before and during the consequent two cycles of chemotherapy in breast cancer patients. Clin Chem Lab Med 2010, 48:1487-1495.

26. Vulimiri SV, Wu X, Baer-Dubowska W, De Andrade M, Detry M, Spitz MR, DiGiovanni J: Analysis of aromatic DNA adducts and 7,8-dihydro-8-oxo-2' deoxyguanosine in lymphocyte DNA from a case-control study of lung cancer involving minority populations. Mol Carcinog 2000, 1:34-47.

27. Obtulowicz T, Swoboda M, Speina E, Gackowski D, Rozalski R, Siomek A, Janik J, Janowska B, Ciesla JM, Jawien A, Banaszkiewicz Z, Guz J, Dziaman T, Szpila A, Olinski R, Tudek B: Oxidative stress and 8-oxoguanine repair are enhanced in colon adenoma and carcinoma patients. Mutagenesis 2010, 25:463-471.

doi:10.1186/1471-2407-14-765

Cite this article as: Buchynska et al.: DNA repair deficiency in peripheral blood lymphocytes of endometrial cancer patients with a family history of cancer. BMC Cancer 2014 14:765.

\section{Submit your next manuscript to BioMed Central and take full advantage of:}

- Convenient online submission

- Thorough peer review

- No space constraints or color figure charges

- Immediate publication on acceptance

- Inclusion in PubMed, CAS, Scopus and Google Scholar

- Research which is freely available for redistribution 